Depositional Systems is a systematic but essentially conventional treatment of sedicontext of stratigraphy. Dr Davis's book is comprised of sixteen chapters, partitioned into four main sections which cover principles, and then terrestrial, transitional and marine environments. The concept underlying the author's treatment is the Brown-Fisher-Scott depositional system, that is, an assemblage of process-related sedimentary facies. This concept, introduced in the 1960 s, is widely used in applied sedimentology, and therefore deserves to be put before undergraduates, but perhaps in a more critical manner than we find here. Under this concept, each system or environment is treated systematically, beginning with an account of its modern expressions in terms of processes and sediments, and concluding with an outline of case-histories drawn from the rock-record in various parts of the world. accurate, attractively written and presented, but essentially descriptive. It is aimed at no particular national market and includes a well-balanced selection of sedimentological examples. My most serious reservation concerns the author's failure adequately to knit his depositional systems together at the basinal level and in the context of modern geodynamical theory; but provided its limitations are recognized, mentary environments and facies in the

Depositional Systems is detailed,

Dr Davis's book deserves to find a wide audience.

Dynamic Stratigraphy is the second and greatly improved edition of a book which appeared in 1974, and which was the first to include the adjective "dynamic" in its title. The main additions are a lengthy section concerned with the geodynamical context of sedimentation, and the enlargement of another to embrace the evolution of sedimentary environments throughout the entire Phanerozoic. The book is in nineteen chapters, grouped into five parts: an introduction; sediments, time and the stratigraphic record; the geodynamical context of sediment accumulation; dynamics in the context of environment; and dynamics in the context of time.

This attractive book is systematic, exact, quantitative and, above all, concerned with general models and root causes. The author has many perceptive things to say about sedimentology and stratigraphy and their practitioners which deserve to be widely read, discussed and acted on, and not just by university and college students. My only regret is that its intellectual appeal is undermined by an over-emphasis on North American work in the field of sedimentology.

J.R.L. Allen is Professor of Geology at the University of Reading.

\section{Talk about the oil} business

\section{B.W. Sellwood}

Petroleum Geology.

By R.E. Chapman.

Elsevier Science: 1983. Pp.415. Dfl.115, $\$ 44.25$.

PETROLEUM geology is that branch of the earth sciences concerned with the discovery, evaluation and production of hydrocarbons. There is need for a textbook on the subject for senior undergraduates and the more general professional. This book is not it.

As a teacher I require an up-to-date, well-organized account of exploration rationale and methods, prospect evaluation techniques and production procedures, accompanied by example casehistories ranging across the globe. Petroleum Geology falls far short of fitting the bill. It is repetitive, packed with homilies, and the organization is poor with general and technical chapters being littered throughout. There are also many inaccuracies; to give just two examples, land plants are asserted to have arisen in the Mesozoic (p.79) and "regression" is stated as being defined as lowering of sea-level (p.9). Some chapters seem strangely dated, relying heavily on older literature (in
Chapter 8 , on petroleum reservoirs, only 9 out of the 27 references cited post-date 1970). In places, where things begin to get interesting, the reader is referred to an unspecified "specialist well-log analyst" (p.115).

I cannot detail here my more specific reservations, but a few examples illustrate the range of problems. Sedimentological aspects of well-log evaluation and reservoir plumbing have been largely ignored, the dipmeter being dismissed in 32 lines. The thin account of drilling dwells on outmoded methods (cable-tool drilling) but ignores bit types and turbo-drilling, and dismisses cuttings as being "almost useless" (p.100) - which they are not. Chapter 7, which falls between chapters on borehole logging and reservoir evaluation, rambles through world and state oil-field rankings, the author spuriously applying Zipf's so-called "law" (on salary distributions!). And while some of the technical chapters are not without merit, the material is more fully covered in Schlumberger and Dresser logging manuals.

Perhaps not surprisingly, the intended readership is never identified. Certainly an undergraduate would find this book heavy going at best and misleading at worst, while professional petroleum geologists will already be familiar with what it contains. $\square$

B.W. Sellwood is a Lecturer in Geology at the University of Reading.

\section{Rock collection}

\section{Reg Bradshaw}

Dictionary of Petrology.

By S.I. Tomkeieff.

Edited by E.K. Walton, B.A.O. Randall,

M.H. Battey and O. Tomkeieff.

Wiley: 1983. Pp.680. £49.50, \$97.50.

Igneous Rocks.

By Daniel S. Barker.

Prentice-Hall: 1983. Pp.417.

$\$ 49.90$, £35.10.

FOLLOWING an abortive collaboration with A. Holmes to produce a second edition of Nomenclature of Petrology (1920), S.I. Tomkeieff conceived the idea of a dictionary which would give the etymology of petrological terms, the development of any meanings with time, and references to their first and subsequent use. Unfortunately he died in 1968 before the work was completed, but his widow enlisted the help of three other editors in preparing his notes for the press. It is clear from the foreword and preface to Dictionary of Petrology that it is not the work that was originally intended - it is shorter, less complete and less concerned with etymology.

The dictionary is in two parts. The first, larger part, is an alphabetical list of some 8,000 terms related principally to igneous, sedimentary and metamorphic rocks but with some from soils, economic and structural geology included (meteorites are excluded). The second consists of synoptic tables in which terms from the first part are re-grouped into lists covering different subject areas within the wide field of petrology.

Petrological nomenclature, particularly that of igneous rocks, is complex and unsystematic, and some rock names still in use can be traced back to Pliny and Theophrastus though their meanings may have changed. So while any attempt to explain terminology is to be welcomed, it has to be said that the treatment here is uneven at all levels. The derivation of most names of igneous rocks is given, often with a reference to their author and first use, but terms of long standing may be referenced to works of the 1970s while others have neither etymology nor reference. Rocks such as granite and greywacke justifiably receive considerable attention, but others are mere local rocks with local names from such places as Reunion, Java or Chile. Some terms such as pingo, overlap, hiatus and yardang can hardly be considered to be petrological.

\section{Geologist's guide}

Field Geology in the British Isles, according to the publisher the first book to cover geological excursions for the whole of the British Isles, has recently been published by Pergamon Press. The author is J. G. C. Anderson, who after a general introduction describes 194 geological itineraries based on a number of centres. Price in flexicover is $£ 8.95, \$ 16$. 